02 Royal Netherlands Institute for Sea Research

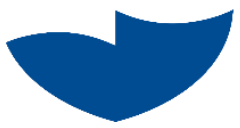

This is a postprint of:

Poiesz, S.; de Vries, A.; Cardoso, J.F.M.F.; Witte, J.IJ.; van der Veer, H.W. \& Freitas, F. (2019) A comparison of growth in two juvenile flatfish species in the Dutch Wadden Sea: Searching for a mechanism for summer growth reduction in flatfish nurseries. Journal of Sea Research, 144, 39-48

Published version: https://dx.doi.org/10.1016/..seares.2018.10.003

Link NIOZ Repository: http://www.vliz.be/imis?module=ref\&refid=303003

[Article begins on next page]

The NIOZ Repository gives free access to the digital collection of the work of the Royal Netherlands Institute for Sea Research. This archive is managed according to the principles of the Open Access Movement, and the Open Archive Initiative. Each publication should be cited to its original source - please use the reference as presented.

When using parts of, or whole publications in your own work, permission from the author(s) or copyright holder(s) is always needed. 


\section{A comparison of growth in two juvenile flatfish species in the Dutch Wadden Sea: searching for a mechanism for summer growth reduction in flatfish nurseries}

Suzanne S.H. Poiesz ${ }^{a}$, Anne de Vries ${ }^{a}$, Joana F.M.F. Cardoso ${ }^{a}$, Johannes IJ. Witte ${ }^{a}$, Henk W. van der Veer ${ }^{a}$, Vânia Freitas ${ }^{a b}$

${ }^{a}$ NIOZ Royal Netherlands Institute for Sea Research, Department of Coastal Systems, and Utrecht University, P.O. Box 59, 1790 AB, Den Burg, Texel, The Netherlands

${ }^{b}$ CIIMAR Interdisciplinary Centre of Marine and Environmental Research, University of Porto, Terminal de Cruzeiros do Porto de Leixões, Av. General Norton de Matos s/n, 4450-208 Matosinhos, Portugal

Keywords: 0-group flatfish, plaice, flounder, nursery ground dynamics, summer growth reduction, dynamic energy budget model, otolith microstructure analysis, Wadden Sea 


\begin{abstract}
Summer growth reduction in juvenile flatfish has been observed in various temperate coastal areas, suggesting a general mechanism. One possible mechanism that might explain this phenomenon is related to trophic limitation. After the spring phytoplankton bloom macrozoobenthic infauna becomes less active above the sediment, thereby affecting the time spent by predatory flatfish on searching for prey and hence, causing a reduction in food intake and in growth. Here, our aim is to gather evidence to substantiate this so-called "summer growth reduction" hypothesis by analyzing summer growth for 0-group flounder Platichthys flesus at the Balgzand intertidal area in the western Dutch Wadden Sea, under the prediction that flounder, as a more epibenthic predator, would suffer less or not at all from summer growth reduction in contrast to 0-group plaice Pleuronectes platessa, a more benthic feeder. Summer growth was studied for three contrasting years with respect to preceding winter water temperature conditions (cold, average and warm year) to exclude possible irreversible non-genetic adaptation of growth to water temperature conditions. Growth performance was analyzed by combining information on individual growth based on otolith daily ring analysis with predictions of maximum growth (= under optimal food conditions) based on a Dynamic Energy Budget model. In line with expectations and in contrast to 0 -group plaice, no trend in growth performance over time was found suggesting that 0 -group flounder showed no growth reduction after summer, providing further basis for a future testing of the trophic limitation hypothesis.
\end{abstract}




\section{Introduction}

Shallow coastal systems are widely recognized as important nurseries for marine fish species (Zijlstra, 1972; reviewed in Beck et al., 2001). For many decades, the focus of research has been on the carrying capacity of these areas in terms of output in numbers and growth conditions (Zijlstra, 1972; MacCall, 1990; Kashiwai, 1995; Le Pape \& Bonhommeau, 2015). The demersal habitat has received particular attention due to the fact that it can be quantitatively studied with small demersal trawls (Kuipers, 1975; Kuipers et al., 1992). Furthermore, in temperate systems, the shallow areas are used by a relatively small number of non-commercially and commercially species, including flatfishes that concentrate in high numbers during early life such as, plaice (Pleuronectes platessa), flounder (Platichthys flesus) and sole (Solea solea) (Riley \& Corlett, 1966; Macer, 1967; Edwards \& Steele, 1968; Kuipers, 1977; Lockwood, 1980; Zijlstra et al., 1982; Berghahn, 1986; van der Veer, 1986; van der Veer et al., 1991, 2001; Nash \& Geffen, 2000, 2012, Teal et al., 2012).

Juvenile growth has been thoroughly studied in coastal nursery areas whereby, over the years, not only tools and methodologies have changed but also the knowledge on the biotic and abiotic factors influencing growth. First studies suggested favorable or even maximum growth and optimal food conditions in several European coastal waters (Zijlstra et al., 1982; van der Veer, 1986; Bergman et al., 1988; Selleslagh \& Amara, 2013). This lead to the formulation of the "maximum growth/optimal food conditions" hypothesis (sensu Karakiri et al., 1991, van der Veer \& Witte, 1993): growth rates in these environments are

maximum and mainly controlled by prevailing water temperatures. Since then, a variety of factors ranging from food quality and quantity (Karakiri et al., 1991; van der Veer \& Witte, 1993), irreversible non-genetic adaptation (van der Veer et al., 2000a) and sex (van der Veer et al., 2016) have been identified as causes of growth variation in juvenile flatfish. In addition, there has been considerable debate on the existence of density-dependent food 
limitation (for overview see Le Pape \& Bonhommeau, 2015). As a consequence, small-scale spatial and temporal heterogeneity in growth and condition of juvenile fish can be expected and this has indeed been found (Ciotti et al., 2013a,b, 2014).

At larger spatial scales, temporal variability in growth among various flatfish species has also been found (Amara, 2003; Fonseca et al., 2006; Hurst \& Abookire, 2006; van der Veer et al., 2010; Freitas et al., 2012, 2016; Ciotti et al., 2013a,b). Growth varies not only among nursery areas but also among cohorts or age groups of a given species and even among subcohorts during settlement (Fonseca et al., 2006). The most prominent pattern was the temporal variation during the year, with a maximum immediately after settlement, and declining to a lower and stable level in summer.

This so-called "summer growth reduction" hypothesis was studied in more detail for 0-group plaice in the western Dutch Wadden Sea, whereby it was postulated that the underlying cause could be a reduction in activity of the infauna after the spring phytoplankton bloom (van der Veer et al., 2016). This reduced benthic activity is thought to cause an increase in searching time for juvenile plaice, ultimately leading to a lower prey intake. This hypothesis was supported by the observed late summer decrease in stomach content biomass in 0-group plaice, and especially of regenerating body parts of macrobenthic prey (Kuipers, 1977; de Vlas, 1979; Freitas et al., 2010). However, conclusions were hampered by the fact that field growth was estimated from shifts in mean size of the population over time, whereby bias such as size-selective predation and/or migration movements could not be excluded (van der Veer et al., 2016). To reduce this bias, the "summer growth reduction" hypothesis was re-evaluated for 0-group plaice using otolith microstructure analysis (Cardoso et al., 2016). The later study confirmed that growth conditions for 0 -group plaice in the western Wadden Sea were not optimal and that a growth reduction occurred in summer, although this decline was smaller than previously observed based on population growth (Freitas et al., 2012). 
Juvenile plaice in the Wadden Sea feeds mainly on a variety of macroozoobenthic prey items, including both polychaetes and bivalves (Kuipers, 1977; de Vlas, 1979). If benthic activity is indeed the key underlying factor for summer growth reduction, then we expect that a predator less reliant upon benthic infauna would exhibit less or even no summer growth reduction. Juvenile flounder Platichthys flesus is more an epibenthic feeder compared to juvenile plaice (de Vlas, 1979). In a comparative study of the diet of juveniles of both species in a tidal flat area of the Dutch Wadden Sea, 0-group flounder diet contained more epibenthic crustaceans (e.g. Corophium sp., Crangon crangon) (de Vlas, 1979). Therefore, in the present study, we evaluated the growth conditions for 0-group flounder in the Balgzand intertidal area of the western Dutch Wadden Sea and compared it with the results obtained for 0 -group plaice. To this end, growth was analyzed in line with the previous study in 0-group plaice by Cardoso et al. (2016), by combining information on individual growth (size-at-post settlement age) derived from otolith microstructure analysis with predictions of maximum growth (i.e. under optimal food conditions) based on a Dynamic Energy Budget model (Kooijman, 2000; 2010). Years with different temperature regimes were selected (1995, a year following a mild winter, 1996 following a severe winter and 2000 following an average winter), since water temperature during early life may affect the growth performance later on in the juvenile life phase due to irreversible non-genetic adaptation of growth to water temperature conditions (van der Veer \& Witte, 1999)

\section{Materials and methods}

\subsection{Sampling}

0-group flounder were sampled at the Balgzand intertidal area of the western Dutch Wadden Sea (Fig. 1). Samples were collected at regular intervals of two to four weeks during the course of the year, from March to August in 1995 (after a warm winter), from 
February to September in 1996 (after a cold winter) and from January to October in 2000 (after an average winter). During each sampling, nine transects, each consisting of four stations were fished for a length of 100 meter with a $2 \mathrm{~m}$ beam trawl ( 1 tickler chain: mesh size of $5 \times 5 \mathrm{~mm}$ ). Sampling occurred between 1.5 hours before until 1.5 hour after high tide, since during this time period the juvenile flatfish population is considered to be randomly distributed over the intertidal area (Kuipers, 1977). The $2 \mathrm{~m}$ beam trawl with a meter-wheel attached to the trawl to assess the correct length of the haul, was towed by a rubber dinghy with a $25 \mathrm{HP}$ outboard engine at a constant speed of about $35 \mathrm{~m} \cdot \mathrm{min}^{-1}$ following Riley \& Corlett (1966). A GPS was used to establish the correct locations. During the hauls, water temperature was measured and compared to a daily temperature series collected from a long-term monitoring station (Marsdiep jetty) located at the southern tip of Texel (van Aken, 2008; Fig. 1). For more information see Zijlstra et al. (1982) and van der Veer (1986).

All catches were transported to the laboratory and frozen at $-20^{\circ} \mathrm{C}$ until further analysis. Within a week, catches were thawed and sorted out for 0-group flounder. In case of doubt, otoliths were removed to check for age. All individuals were measured to the nearest $\mathrm{mm}$ total length and subsequently fixed in $70 \%$ alcohol. In line with previous work (van der Veer et al., 1991), all numbers caught were corrected for size-selective mesh efficiency after Dapper (1978) and catch efficiency after Kuipers (1975), using the data for plaice. For each haul, corrected numbers were converted into densities per $1000 \mathrm{~m}^{2}$ (ind. $\left.\left[10^{3} \mathrm{~m}^{2}\right]^{-1}\right)$ and the arithmetic mean was calculated for each survey as an index of population abundance on the tidal flats at high water. In addition, for each haul, the mean length was determined and subsequently, the arithmetic mean of all catches was considered to represent the mean length of the population.

\subsection{Otolith analysis}


For each year, a number of fish were selected from all cruises in relation to their abundance for further otolith analysis: a total of 554 fishes in 1995, 448 in 1996 and 291 in 2000. Otolith analysis was done in line and similar to the methods described by Cardoso et al. (2016). In short, from each fish, both sagittal otoliths were removed and whenever possible, the left otolith was selected, cleaned and air-dried for further analysis. For fish smaller than 30-35 mm, counting of the daily rings was done directly. For larger fish and hence larger otoliths with multiple layers, the otoliths were polished prior to reading. A drop of a thermoplastic adhesive (Crystalbond, Buehler, USA) was placed on the otolith with the sulcus facing upwards. After the thermoplastic adhesive had hardened, grinding and polishing were done by several grinding plates from coarse to fine (P1200, P2500 and P4000 silicon carbide abrasive papers; Buehler) and wet-polished (MasterPrep, Buehler) until the midplane of the otolith was visible. Next, the otolith was turned with the sulcus and ground surface facing downward, and the grinding and polishing steps were repeated on the unground side.

Daily rings (increments) were counted with a light microscope (Zeiss) coupled to a digital camera (AxioCam ICc3, Zeiss, Germany). Rings were counted from the first ring after the first accessory growth center, which was considered to be the first daily ring after settlement (following Geffen et al., 2011), until the edge of the otolith. Counting was done by two experienced observers separately. When both counts differed by more than $10 \%$, counting was repeated. If, after two counting rounds, the difference was still larger than $10 \%$, then the otolith was excluded from further analysis. For each otolith (and fish), the mean of both counts was taken and considered to represent the age in days after settlement. Individual settlement date was determined by subtracting the number of counted rings (age in days) from the catch date.

\subsection{Growth analysis}




\subsubsection{Field growth}

The observed settlement period was split up in weekly periods (hereinafter referred to as cohorts). For each year, individual fish were assigned to the various cohorts based on their back-calculated settlement date. Subsequently, for each cohort, the age - length relationship was determined based on the otolith daily ring counts in combination with fish size.

\subsubsection{Theoretical maximum growth}

To calculate the theoretical maximum growth trajectories, a Dynamic Energy Budget (DEB) model (Kooijman, 2010) was used. A thorough description of the standard DEB model and relevant equations are given in van der Veer et al. (2010; Eqs. 1-:4). Species-specific model parameter values for flounder were taken from van der Veer et al. (2001, 2009, 2010) and Freitas et al. (2010) (Supplementary information Table S1). Previous work on various flatfish species in different nurseries has confirmed the robustness of the DEB parameters (Freitas et al., 2012).

The forcing variables of the DEB model are food density and water temperature whereby the former is linked to assimilated energy via the scaled functional response ( $f$ ), a dimensionless parameter varying between 0 (representing starvation) and 1 (ad libitum food). In this study we assume unlimited and constant food conditions which, in this case simplify the DEB model equations describing the growth dynamics into the Von Bertalanffy growth model (Kooijman, 2010):

$$
\frac{d}{d t} L=\dot{\Gamma}_{\mathrm{B}}\left(L_{\infty}-L\right)
$$


The parameters $L_{\infty}$ (ultimate size; $\mathrm{cm}$ ), $L$ (observed length; $\mathrm{cm}$ ) and $r_{B}$ (von Bertalanffy growth rate constant, $\mathrm{d}^{-1}$ ) can thus be written as a combination of DEB parameters described in equations 2 and 3 :

$$
\begin{gathered}
L_{\infty}=f \frac{L_{\mathrm{m}}}{\delta_{\mathrm{M}}}=f \frac{\dot{\mathrm{v}}}{g \dot{\mathrm{k}}_{\mathrm{M}} \delta_{\mathrm{M}}} \\
\dot{\Gamma}_{\mathrm{B}}=\frac{1}{3 / \dot{\mathrm{k}}_{\mathrm{M}}+3 f L_{\mathrm{m}} / \dot{v}}=\frac{\dot{\mathrm{k}}_{\mathrm{M}} / 3}{1+f / g}
\end{gathered}
$$

where $f$ is the scaled functional response (dimensionless), $\delta_{M}$ is the shape coefficient $(-), L_{m}$ the maximum volumetric length $(\mathrm{cm}), \dot{v}$ is the energy conductance $\left(\mathrm{cm} \mathrm{d}^{-1}\right), \mathrm{g}$ is the investment ratio (-) that stands for the costs of new bio volume relative to the maximum potentially available energy for growth and maintenance, and $\dot{K}_{M}$ is the maintenance rate coefficient $\left(\mathrm{d}^{-1}\right)$, which stands for the ratio of somatic maintenance costs to structure (van der Veer et al., 2010).

Growth rates are affected not only by food availability but also by temperature conditions, due to the temperature dependence of physiological rates. All DEB model parameters representing rates (e.g. $\dot{\mathrm{V}}, \dot{\mathrm{K}}_{\mathrm{M}}$ ) are thus affected by temperature and this thermal dependence is described using an Arrhenius-type relationship extended to account for the effects of temperature at both lower and upper tolerance boundaries for the species (Kooijman 2010, p. 21; van der Veer et al. 2010, Eq. 4):

$$
\dot{k}(T)=k_{1} \mathrm{e}^{\left(\frac{T_{\mathrm{A}}}{T_{1}}-\frac{T_{\mathrm{A}}}{T}\right)} \cdot \frac{1+\mathrm{e}^{\left(\frac{T_{\mathrm{AL}}}{T_{1}}-\frac{T_{\mathrm{AL}}}{T_{\mathrm{L}}}\right)}+\mathrm{e}^{\left(\frac{T_{\mathrm{AH}}}{T_{\mathrm{H}}}-\frac{T_{\mathrm{AH}}}{T_{1}}\right)}}{1+\mathrm{e}^{\left(\frac{T_{\mathrm{AL}}}{T}-\frac{T_{\mathrm{AL}}}{T_{\mathrm{L}}}\right)}+\mathrm{e}^{\left(\frac{T_{\mathrm{AH}}}{T_{\mathrm{H}}}-\frac{T_{\mathrm{AH}}}{T}\right)}}
$$


where $T$ is absolute temperature $(\mathrm{K}), T_{\mathrm{AL}}$ and $T_{\mathrm{AH}}$ are Arrhenius temperatures $(\mathrm{K})$ for the rate of decrease at the lower $\left(T_{\mathrm{L}}\right)$ and upper $\left(T_{\mathrm{H}}\right)$ boundaries, respectively. $T_{1}$ is the reference temperature, $T_{\mathrm{A}}$ the Arrhenius temperature, and $k_{1}$ is the rate at the reference temperature. For parameter values see Supplementary Table S1.

Mean daily temperature data were derived from measurements taken every 30 minutes at the Marsdiep jetty (van Aken, 2008) in 1995, 1996 and 2000.

For the three years, for each settling cohort a prediction of size (length) over time was made with the DEB model, assuming a starting length of $10 \mathrm{~mm}$, unlimited and constant supply of food $(f=1)$ and the prevailing water temperatures. In DEB models, differences in energy budgets between sexes are reflected in different parameter values namely in those related to energy allocation (e.g. reproductive investment) and/or energy acquisition (ingestion, assimilation) (Kooijman, 2010), and consequently, on their growth dynamics. Therefore, maximum growth predictions were made for both males and females separately (van der Veer et al., 2009; Cardoso et al. 2016).

\subsubsection{Realized growth}

Realized growth (RG, dimensionless), defined as the ratio between observed size and DEB-predicted maximum size under optimal food conditions, was calculated for each individual flounder separately and for all three years. For comparison with field growth where sexes were not distinguished, DEB-predicted maximum growth for males and females were first averaged assuming that in the nursery ground the sex ratio was $1: 1$.

\subsection{Statistical analysis}

All statistical analyses were carried out with the $\mathrm{R}$ package programming environment ( $R$ Core Team, 2017). The water temperatures measured at Balgzand were 
compared with daily records obtained from a long-term monitoring program at a nearby area (Marsdiep) using an analysis of covariance (ANCOVA). 0-group flounder growth was compared among settling cohorts and between years using ANCOVA. Comparison between observed length in the field and maximum length based on DEB model predictions was conducted using analysis of variance (ANOVA) (following Cardoso et al., 2016). Temporal reductions in realized growth (RG) were visually assessed by plotting RG along sampling date and averages were analyzed over time.

Model validation was done in line with previous analysis for plaice following Zuur et al. (2009). For the various tests, model assumptions with respect to homogeneity, normality, independence, and absence of influential observations were met.

\section{Results}

\subsection{Water temperature}

Daily temperatures measured at the Marsdiep jetty during 1995, 1996 and 2000 were used instead of the less frequent water temperature measurements taken during sampling, since no significant differences were found between them (ANCOVA, $\mathrm{p}$-value = 0.355). (Fig. 2).

\subsection{Abundance and growth}

0-group flounder were first found in the catches in April in 1995, May in 1996 and in

mid-April in 2000, and were present until August in all three years. Seasonal patterns in abundance varied between years with peak densities up to 400 ind. $\left[10^{3} \mathrm{~m}^{2}\right]^{-1}$ in 1995 , compared with about 225 in 1996 and less than 100 in 2000 (Fig. 3a). Maximum densities occurred by the end of April in 2000 and later in 1995 (middle of May) and 1996 (beginning 
of June). Mean length per sampling date was generally larger in 2000 than in the other years, especially compared to 1996 which showed a time lag in the increase in length (Fig. 3b) due to delayed settlement. However, the growth trajectory in all three years was generally similar. In August, 0-group flounder reached a maximum size of $87 \mathrm{~mm}$ in 1995 and $76 \mathrm{~mm}$ in 1996 and $78 \mathrm{~mm}$ in 2000 (Fig. 4). The smallest individuals found in all years were $9-10 \mathrm{~mm}$ total length.

Counting of otolith daily increments did not differ between observers (Student's ttest, $\mathrm{p}$-value $=0.76$ ). Back-calculation of settlement date revealed that settlement occurred over a period of 6 (1996 and 2000) to 8 weeks (1995) (Fig. 5). Settlement started in 1995 in Mid-March (18 March), in 1996 in mid-April (18 April) and in 2000 at the beginning of April (4 April). The peak in settlement date was also later in 1996 than in 1995 and 2000, around late April in 1995 and 2000 and two to four weeks later in 1996 (Fig. 5).

\subsection{Realized growth}

The observed length of 0 -group flounder over all three years for each settling cohort together with the averaged DEB-predicted maximum growth trajectories of male and female are shown in Fig. 6. For 1995, 1996 and 2000, there was a good fit between observed and predicted length (ANOVA; for all three years, $\mathrm{p}<0.001$; Supplementary Data Fig. S1).

Overall, there was variation in RG based on individual observations, with values ranging from 0.6 (in 1995 and 1996) to a maximum of 1.6 (in 2000) (Fig. 7) Values above 1.0 will reflect males and values below 1 females. The average RG showed a very slight increase over time in 1996 and 2000 and from mid-may onwards in 1995, indicating relatively stable growth conditions over the season. Although temporal patterns were similar between years, the RG in 1996 was on average at a lower level (0.89) than in the other two years (0.93 in 1995; 1.04 in 2000) suggesting that in 1996 sex ratio was not $1: 1$. In all three years, no decline in RG was found over time.. 


\section{Discussion}

\subsection{Flounder life cycle}

In the North Sea region, the life cycle of flounder resembles that of plaice. For both species, spawning areas are located in the open North Sea and show a spatial overlap (Harding et al., 1978). As in plaice, large quantities of small larvae emigrate from the North Sea into the Wadden Sea every year in spring and settle in this area (Creutzberg et al., 1978; van der Veer, 1986; van der Veer et al., 1991). Spawning areas of plaice are located more offshore and the timing differs, with plaice spawning earlier than flounder (van der Land, 1991). In addition, immigrating and settling larvae differ in size with an average size of $13 \mathrm{~mm}$ in plaice versus $9-10 \mathrm{~mm}$ in flounder (Creutzberg et al., 1978; van der Veer, 1986; van der Veer et al., 1991), reflecting the smaller egg size of flounder (Russell, 1976; van der Veer et al., 2003). During settling, plaice has been found to prefer polyhaline areas whereas flounder is typically found near freshwater inlets (de Vlas, 1979; Kerstan, 1991; Bos \& Thiel, 2006).

For both species, interannual variability in the abundance of settling larvae and hence in year-class strength is observed (Creutzberg et al., 1978; Zijlstra et al., 1982; van der Veer, 1986; van der Veer et al., 1991; van der Veer \& Witte, 1999; Jung et al., 2017). Although immigration of plaice and flounder partly overlap, plaice immigration starts on average about 1 month earlier than that in flounder (van der Veer, 1986; van der Veer et al., 1991). For both species, year-class strength is determined during egg and/or larval development at open sea (van der Veer, 1986; van der Veer et al., 1991, 2000b; Leggett \& DeBlois, 1994). However, the underlying mechanisms might differ. While in plaice an inverse relationship exists between winter temperature and year-class strength (van der Veer, 1986; van der Veer \& Witte, 1999), such relationship is absent in flounder (van der 
Veer et al., 1991), as also becomes clear in the present study. Although, as in plaice, flounder larval immigration is delayed after a severe winter due to reduced water temperature during drift and hence the longer period of development, year-class strength was in fact strongest in 1995, after a mild winter, than in 1996 after a very cold winter.

Otolith microstructure analysis showed differences in settlement date of flounder among years. In 1996, the peak in settlement happened two to four weeks later than in the other two years. The most evident cause of settlement delay and thus later larval immigration in 1996 might have been the exposure to colder temperatures until later in the year (until April) when compared to years with milder or average winters (colder temperatures until March; van der Veer \& Witte, 1999).

Due to the fact that flounder larval immigration occurs on average 1 month later than that of plaice, flounder has a shorter growing season. Furthermore, in combination with their smaller larval size, flounder reach an average size at the end of their first growing season of about $7 \mathrm{~cm}$ compared with $10 \mathrm{~cm}$ in plaice (Cardoso et al., 2016; this study).

\subsection{Flounder growth conditions}

Theoretical growth trajectories predicted by the DEB model were made assuming an unlimited food source with year-specific water temperatures, the so-called "maximum growth/optimal food condition" hypothesis (van der Veer \& Witte, 1993; van der Veer et al., 2001). Although no differences in realized growth were observed between the years, the impact of temperature on flatfish growth has been confirmed by numerous studies (AlHossaini et al., 1989; Fonds et al., 1992; Modin and Pihl, 1994; Nash et al., 1994; Amara, 2003, 2004; Teal et al., 2008; Gunnarsson et al., 2010; Geffen et al., 2011). The effect of late settlement and low temperature in the beginning of the year (average of $0^{\circ} \mathrm{C}$ ) in 1996 , when compared to 1995 and 2000 (average of $5^{\circ} \mathrm{C}$ ), is reflected on the average length of the 0-group population which is significantly lower in 1996 compared to 1995 and 2000. 
Settlement of flounder larvae extended over a period of about a maximum of two months, which is shorter than the period of plaice larval immigration in the same area (Creutzberg et al., 1978; van der Veer, 1986; Cardoso et al., 2016). Similar to plaice, growth conditions for flounder were analyzed for various settling cohorts which, in this case, were assigned as 7-day groups of settlement. For most cohorts, field data were restricted to the smallest sizes only and for some cohorts in some years hardly any field observations were present. This resulted in incomplete growth trajectories for a number of cohorts and hence an insufficient amount of data for comparison with model simulations. Therefore, data were pooled for all cohorts together. It cannot be excluded that different sub cohorts differ in intrinsic growth rates, as has been found for plaice, due to differences in sex ratio (van der Veer et al., 2016) or in ontogenetic background (Kinne, 1962; van der Veer et al., 2000a). However, a common-garden growth experiment with two different populations of juvenile plaice from the Scottish west coast, revealed that systematic differences in size between nursery sites were not driven by differences in intrinsic growth potential but rather by nursery ground quality (Fox et al., 2014). Therefore, we would expect that for flounder in the Balgzand area, growth differences between cohorts would also be small.

For all three years, the average realized growth (RG) differed from 1.0 and also varied slightly among years (1995: $0.93 ; 1996: 0.89 ; 2000: 1.04)$. This might suggest that the sex ratios differed from $1: 1$ and also differed among years. Furthermore, the absence of a decrease in realized growth in flounder indicates no summer growth reduction in contrast to plaice (Ciotti et al., 2013a,b; Freitas et al., 2012, 2016; van der Veer et al., 2010; Cardoso et al., 2016). This confirms results of a previous growth analysis for flounder based on shifts in population mean size for the same area (Freitas et al., 2012). These results provide further support to the formulation of a hypothesis to be tested in the future, about the causes of the summer growth decline in some flatfish species but not in others, namely a trophic mechanism. 


\subsection{Feeding traits and summer growth reduction}

The observed differences in summer growth between plaice (reduction) and flounder (no reduction) are in line with the "summer growth reduction" hypothesis where a link is made with the seasonal production cycle of the system. After the spring phytoplankton bloom, primary production decreases and, as a consequence, macrozoobenthos becomes less active. Strong support is provided by the seasonal growth pattern in the bivalve Macoma balthica in various areas, which shows only a short growing season followed by a long period of weight loss (Beukema \& de Bruin, 1977; Nichols \& Thompson, 1982). This leads to a reduction in prey availability during the summer for predatory benthic flatfish, causing more searching time and a reduction of the time for food intake (van der Veer et al., 2016), with food limitation affecting growth (Le Pape \& Bonhommeau., 2015; Tableau et al., 2016). In contrast to benthic prey items, epibenthic prey items such as the Cranqon crangon remain present and also would not show any weight loss after summer, as they are omnivorous and prey on various benthic and epibenthic species (Oh et al., 2001). In line with this hypothesis, epibenthic predators, such as flounder, do not suffer from summer growth reduction.

The next step in testing the "summer growth reduction" hypothesis would be to focus on seasonal patterns in benthic activity as done by Moodley et al. (1998) in the northwestern Adriatic Sea. Another option would be focusing on a fully benthic feeding flatfish or other fish species. The sole (Solea solea) might be a good candidate for such an analysis. Also of interest would be an analysis with latitude, to test whether in parallel with a shorter seasonal signal in primary production, there is also a trend of increasing summer growth reduction. In fact, results from Freitas et al. (2012) seem to support this hypothesis: in plaice, declines in realized growth over summer were stronger (as indicated by the slopes of realized growth over time) in northern compared to southern locations, while not enough data were available to analyze the pattern in flounder and sole. 
In the present study, no evidence is found for summer growth reduction in 0 -group flounder, in contrast to what was found for plaice by Cardoso et al. (2016). This shows that two apparently similar species may respond differently to ecological changes and strengthens the importance of predicting possible shifts in fish populations.

\section{Acknowledgements}

Thanks are due to all participants in the Balgzand high-water program over the years. Special thanks are due to the skippers of the NIOZ RV 'Griend' and 'Stern'. Vânia Freitas was supported by the grant SFRH/BPD/75858/2011 from Fundação para a Ciência e a Tecnologia (FCT, Portugal) co-financed by (national funds MCTES) and by the European Social Fund (POPH-QREN-FSE). 


\section{References}

van Aken, H.M., 2008. Variability of the water temperature in the western Wadden Sea on tidal to centennial time scales. J. Sea Res. 60, 227-234.

Al-Hossaini, M., Liu, Q., Pitcher, T.J., 1989. Otolith microstructure indicating growth and mortality among plaice, Pleuronectes platessa L., post-larval sub-cohorts. J. Fish Biol. 35 (Suppl. A), 81-90.

Amara, R., 2003. Seasonal ichthyodiversity and growth patterns of juvenile flatfish on a nursery ground in the Southern Bight of the North Sea (France). Environm. Biol. Fishes, 67, 191-201.

Amara, R., 2004. 0-group flatfish growth conditions on a nursery ground (Bay of Canche, Eastern English Channel). Hydrobiologia 518, 23-32.

Beck, M.W., Heck Jr, K.L., Able, K.W., Childers, D.L., Eggleston, D.B., Gillanders, B.M., Halpern, B., Hays, C.G., Hoshino, K., Minello, T.J., Orth, R.J., Sheridan, P.F., Weinstein, M.P., 2001. The identification, conservation, and management of estuarine and marine nurseries for fish and invertebrates. BioScience, 5, 633-641.

Berghahn, R., 1986. Determining abundance, distribution and mortality of 0-group plaice (Pleuronectes platessa L.) in the Wadden Sea. J. Appl. Ichthyol. 2, 11-22.

Bergman, M.J.N., van der Veer, H.W., Zijlstra, J.J., 1988. Plaice nurseries: effects on recruitment. J. Fish Biol. 33 (Suppl. A), 201-218.

Beukema, J.J., de Bruin, W., 1977. Seasonal changes in dry weight and chemical composition of the soft parts of the tellinid bivalve Macoma balthica in the Dutch Wadden Sea. Neth. J. Sea Res. 11, 42-55.

Bos, A.R., Thiel, R., 2006. Influence of salinity on the migration of postlarval and juvenile flounder Pleuronectes flesus L. in a gradient experiment. J Fish Biol., 68, 1411-1420. 
Cardoso, J.F.M.F., Freitas, V., de Paoli, H., Witte, J.IJ., van der Veer, H.W., 2016. Growth conditions of 0 -group plaice Pleuronectes platessa in the western Wadden Sea as revealed by otolith microstructure analysis. J. Sea Res. 111, 88-96.

Ciotti, B.J., Targett, T.E., Burrows, M.T., 2013a. Decline in growth rates of juvenile European plaice (Pleuronectes platessa) during summer at nursery beaches along the west coast of Scotland. Can. J. Fish. Aquat. Sci. 70, 720-734.

Ciotti, B.J., Targett, T.E., Burrows, M.T., 2013b. Spatial variation in growth rate of early juvenile European plaice Pleuronectes platessa. Mar. Ecol. Prog. Ser. 475, 213-232.

Ciotti, B.J., Targett, T.E., Nash, R.D., Geffen, A.J., 2014. Growth dynamics of European plaice Pleuronectes platessa L. in nursery areas: a review. J. Sea Res. 90, 64-82.

Creutzberg, F., Eltink, A.Th.G.W., van Noort, G.J., 1978. The migration of plaice larvae Pleuronectes platessa into the western Wadden Sea. In: McLusky, D.S., Berry, A.J. (ed.) Physiology and behaviour of marine organisms. Proc. 12th Europ. mar. biol. Symp. Pergamon Press, New York, p. 243-251.

Dapper, R., 1978. De Balgzand scholgegevens 1975, 1976, 1977. Interne verslagen Nederlands Instituut voor Onderzoek der Zee, Texel, 1978-12, p. 1-53.

de Vlas J., 1979. Annual food intake by plaice and flounder in a tidal flat area in the Dutch Wadden Sea, with special reference to consumption of regenerating parts of macrobenthic prey. Neth. J. Sea. Res. 13, 117-153

Edwards, R., Steele, J.H., 1968. The ecology of 0-group plaice and common dabs at Loch Ewe. I. Population and food. J. Exp. Mar. Biol. Ecol. 2, 15-38.

Fox, C.J., Targett, T.E., Ciotti, B.J., de Kroon, K., Hortsmeyer, L., Burrows, M.T., 2014. Size variation of 0-group plaice: are earlier influences on growth potential a contributing factor? J. Sea Res. 88, 59-66.

Freitas, V., Cardoso, J.F.M.F., Lika, K., Peck, M.A., Campos, J., Kooijman, S.A.L.M., van der Veer, H.W., 2010. Temperature tolerance and energetics: a dynamic energy budget 
based comparison of North Atlantic marine species. Phil. Trans. R. Soc. B 365, 35533565.

Freitas, V., Campos, J., Skreslet, S., van der Veer, H.W., 2010. Habitat quality of a subarctic nursery ground for 0-group plaice (Pleuronectes platessa L.). J. Sea Res. 64, 26-33.

Freitas, V., Kooijman, S.A.L.M., van der Veer, H.W., 2012. Latitudinal trends in habitat quality of shallow water flatfish nurseries. Mar. Ecol. Prog. Ser. 471, 203-214.

Freitas, V., Witte, J.IJ., Tulp, I., van der Veer, H.W., 2016. Shifts in nursery habitat utilization by 0 -group plaice in the western Dutch Wadden Sea. J. Sea Res. 111, 6575.

Fonds, M., Cronie, R., Vethaak, A.D., van der Puyl, P., 1992. Metabolism, food consumption and growth of plaice (Pleuronectes platessa) and flounder (Platichthys flesus) in relation to fish size and temperature. Neth. J. Sea Res. 29, 127-143.

Fonseca, V.F., Vinagre, C., Cabral, H.N., 2006. Growth variability of juvenile soles Solea solea and Solea senegalensis, and comparison with RNA:DNA ratios in the Tagus estuary, Portugal. J. Fish Biol. 68, 1551-1562.

Geffen, A.J., Nash, R.D.M., Dau, K., Harwood, A.J.P., 2011. Sub-cohort dynamics of 0-group plaice, Pleuronectes platessa L., in the northern Irish Sea: settlement, growth and mortality. J. Exp. Mar. Biol. Ecol. 400, 108-119.

Gunnarsson, B., Jonasson, J.P., McAdam, B.J., 2010. Variation in hatch date distributions, settlement and growth of juvenile plaice (Pleuronectes platessa L.) in Icelandic waters. J. Sea Res. 64, 60-66.

Harding, D., Nichols, J.H., Tungate, D.S., 1978. The spawning of plaice (Pleuronectes platessa L.) in the southern North Sea and English Channel. Rapp. P.-v. Réun. Cons. int. Explor. Mer 172, 102-113.

Hurst, T.P., Abookire, A.A., 2006. Temporal and spatial variation in potential and realized growth rates of age-0 year northern rock sole. J. Fish Biol. 68, 905-919. 
Jung, A.S., Dekker, R., Germain, M., Philippart, C.J.M., Witte, J.IJ., van der Veer, H.W., 2017. Decadal shifts in intertidal predator and prey communities in the Wadden Sea and consequences for food requirements and supply. Mar. Ecol. Prog. Ser. 579, 37-53. Karakiri, M., Berghahn, R., van der Veer, H.W., 1991. Variations in settlement and growth of 0-group plaice (Pleuronectes platessa L.) in the Dutch Wadden Sea as determined by otolith microstructure analysis. Neth. J. Sea Res. 27, 345-351.

Kashiwai, M., 1995. History of carrying capacity concept and an index of ecosystem productivity (Review). Bull. Hokkaido Nat. Fish. Res. Inst. 59, 81-100.

Kerstan, M., 1991. The importance of rivers as nursery grounds for 0-group and 1-group flounder (Platichthys flesus) in comparison to the Wadden Sea. Neth. J. Sea. Res. 27, 353-366.

Kinne, O., 1962. Irreversible nongenetic adaptation. Comp. Biochem. Phys. 5, 265-282.

Kooijman, S.A.L.M., 2000. Dynamic energy and mass budgets in biological systems. Cambridge University Press, Cambridge, UK.

Kooijman, S.A.L.M., 2010. Dynamic energy budget theory for metabolic organization. Cambridge University Press, Cambridge, UK.

Kuipers, B.R., 1975. On the efficiency of a two meter beam trawl in juvenile plaice (Pleuronectes platessa). Neth. J. Sea. Res. 9, 69-85.

Kuipers, B.R., 1977. On the ecology of juvenile plaice on a tidal flat in the Wadden Sea. Neth. J. Sea Res. 11, 56-91.

Kuipers, B.R., MacCurrin, B., Miller, J.M., van der Veer, H.W., Witte, J.IJ., 1992. Small trawls in juvenile flatfish research: their development and efficiency. Neth. J. Sea Res. 29, 109-117.

Leggett, W.C., DeBlois, E., 1994. Recruitment in marine fishes: is it regulated by starvation and predation in the egg and larval stages? Neth. J. Sea Res. 32, 119-134.

Le Pape, O., Bonhommeau, S., 2015. The food limitation hypothesis for juvenile marine fish. Fish Fisheries 16, 373-398. 
Lockwood, S.J., 1980. The daily food intake of 0-group plaice (Pleuronectes platessa L.) under natural conditions. J. Cons. Int. Explor. Mer 39, 154-159.

MacCall, A.D., 1990. Dynamic geography of marine fish populations. University of Washington Press, Seattle, WA, U.S.A.

Macer, C.T., 1967. The food web in Red Wharf Bay (North Wales) with particular reference to young plaice (Pleuronectes platessa). Helgol. Meeresunters. 15, 560-573.

Modin, J., Pihl, L., 1994. Differences in growth and mortality of juvenile plaice, Pleuronectes platessa L., following normal and extremely high settlement. Neth. J. Sea Res. 32, $331-341$.

Moodley, L., Heip, C.H.R., Middelburg, J.J., 1998. Benthic activity in sediments of the northwestern Adriatic Sea: sediment oxygen consumption, macro- and meiofauna dynamics. J. Sea Res. 40, 263-280.

Nash, R.D.M., Geffen, A.J., Hughes, G., 1994. Individual growth of juvenile plaice (Pleuronectes platessa L.) on a small Irish Sea nursery ground (Port-Erin Bay, Isle-ofMan, UK). Neth. J. Sea Res. 32, 369-378.

Nash, R.D.M., Geffen, A.J., 2000. The influence of nursery ground processes in the determination of year-class strength in juvenile plaice Pleuronectes platessa L. in Port Erin Bay, Irish Sea. J. Sea Res. 44, 101-110.

Nash, R.D.M., Geffen, A.J., 2012. Mortality through the early life-history of fish: What can we learn from European plaice (Pleuronectes platessa L.)?. J. Mar. Sys. 93, 58-68.

Nichols, F.H., Thompson, J.K., 1982. Seasonal growth in the bivalve Macoma balthica near the southern limit of its range. Estuaries 5, 110-120.

Oh, C.W., Hartnoll, R.G., Nash, R.D.M., 2001. Feeding ecology of the common shrimp Crangon crangon in Port Erin Bay, Isle of Man, Irish Sea. Mar. Ecol. Prog. Ser. 214, 211-223.

R Core Team (2017). R: A language and environment for statistical computing. R Foundation for Statistical Computing, Vienna, Austria. URL http://www.R-project.org/. 
Riley, J.D., Corlett, J., 1966. The numbers of 0-group plaice in Port Erin Bay, 1964-66. Rep. Mar. Biol. Stn. Port Erin 78, 51-56.

Russell, F.S., 1976. The eggs and planktonic stages of British marine fishes. Acad. Press, London, U.K. 524 p.

Selleslagh, J., Amara, R., 2013. Effect of starvation on condition and growth of juvenile plaice Pleuronectes platessa: nursery habitat quality assessment during the settlement period. J. Mar. Biol. Ass. U.K. 93, 479-488.

Tableau, A., Brind'Amour, A., Woillez, M., Le Bris, H., 2016. Influence of food availability on the spatial distribution of juvenile fish within soft sediment nursery habitats. J. Sea Res. $111,76-87$.

Teal, L.R., de Leeuw, J.L., van der Veer, H.W., Rijnsdorp, A.D., 2008. Effects of climate change on growth of 0-group sole and plaice. Mar. Ecol. Prog. Ser. 358, 219-230.

Teal, L. R., van Hal, R., van Kooten, T., Ruardij, P., Rijnsdorp, A.D., 2012. Bio-energetics underpins the spatial response of North Sea plaice (Pleuronectes platessa L.) and sole (Solea solea L.) to climate change. Glob. Chang. Biol. 18, 3291-3305.

van der Land, M.A., 1991. Distribution of flatfish eggs in the 1989 egg surveys in the southeastern North Sea, and mortality of plaice and sole eggs. Neth. J. Sea Res. 27, 277-286.

van der Veer, H.W., 1986. Immigration, settlement, and density-dependent mortality of a larval and early postlarval 0-group plaice (Pleuronectes platessa) population in the western Wadden Sea. Mar. Ecol. Prog. Ser. 29, 223-236.

van der Veer, H.W., Bergman, M.J.N., Dapper, R., Witte, J.IJ., 1991. Population dynamics of an intertidal 0-group flounder Platichthys flesus population in the western Dutch Wadden Sea. Mar. Ecol. Prog. Ser. 73, 141-148.

van der Veer, H.W., Bies, B., Witte, J.IJ., 2000a. Selective growth and mortality of juvenile 0-group plaice Pleuronectes platessa L. in the Dutch Wadden Sea: a consequence of 
irreversible non-genetic adaptation during early pelagic life. Mar. Ecol. Prog. Ser. 197, 273-283.

van der Veer, H.W., Cardoso, J.F.M.F., Peck, M.A., Kooijman, S.A.L.M., 2009. Physiological performance of plaice Pleuronectes platessa (L.): A comparison of static and dynamic energy budgets. J. Sea Res. 62, 83-92.

van der Veer, H.W., Freitas, V., Koot, J., Witte, J.IJ., Zuur, A.F., 2010. Food limitation in epibenthic species in temperate intertidal systems in summer: analysis of 0 -group plaice Pleuronectes platessa. Mar. Ecol. Prog. Ser. 416, 215-227.

van der Veer, H.W., Geffen, A.J., Witte, J.IJ., 2000b. Exceptionally strong year classes in plaice Pleuronectes platessa: are they generated during the pelagic stage only or also in the juvenile stage? Mar. Ecol. Prog. Ser. 199, 255-262.

van der Veer, H.W., Jung, A.S., Freitas, V., Philippart, C.J.M., Witte, J.IJ., 2016. Possible causes for growth variability and summer growth reduction in juvenile plaice Pleuronectes platessa L. in the western Dutch Wadden Sea. J. Sea Res. 111, 97-106.

van der Veer, H.W., Kooijman, S.A.L.M., van der Meer, J., 2001. Intra- and interspecies comparison of energy flow in North Atlantic flatfish species by means of dynamic energy budgets. J. Sea Res. 45, 303-320.

van der Veer, H.W., Kooijman, S.A.L.M., van der Meer, J., 2003. Body size scaling relationships in flatfish as predicted by Dynamic Energy Budgets (DEB theory): implications for recruitment. J. Sea Res. 50, 255-270.

van der Veer, H.W., Witte, J.IJ., 1993. The 'maximum growth/optimal food condition' hypothesis: a test for 0-group plaice Pleuronectes platessa in the Dutch Wadden Sea. Mar. Ecol. Prog. Ser. 101, 81-90.

van der Veer, H.W., Witte, J.IJ., 1999. Year-class strength of plaice Pleuronectes platessa in the Southern Bight of the North Sea: a validation and analysis of the inverse relationship with winter seawater temperature. Mar. Ecol. Prog. Ser. 184, 245-257. 
Zijlstra, J.J., 1972. On the importance of the Waddensea as a nursery area in relation to the conservation of the southern North Sea fishery resources. Symp. Zool. Soc. Lond. 29, 233-258.

Zijlstra, J.J., Dapper, R., Witte, J.IJ., 1982. Settlement, growth and mortality of post-larval plaice (Pleuronectes platessa L.) in the western Wadden Sea. Neth. J. Sea Res. 15, $250-272$.

Zuur, A.F., Ieno, E.N., Walker, N.J., Saveliev, A.A., Smith, G., 2009. Mixed effects models and extensions in ecology with R. Springer, New York. 

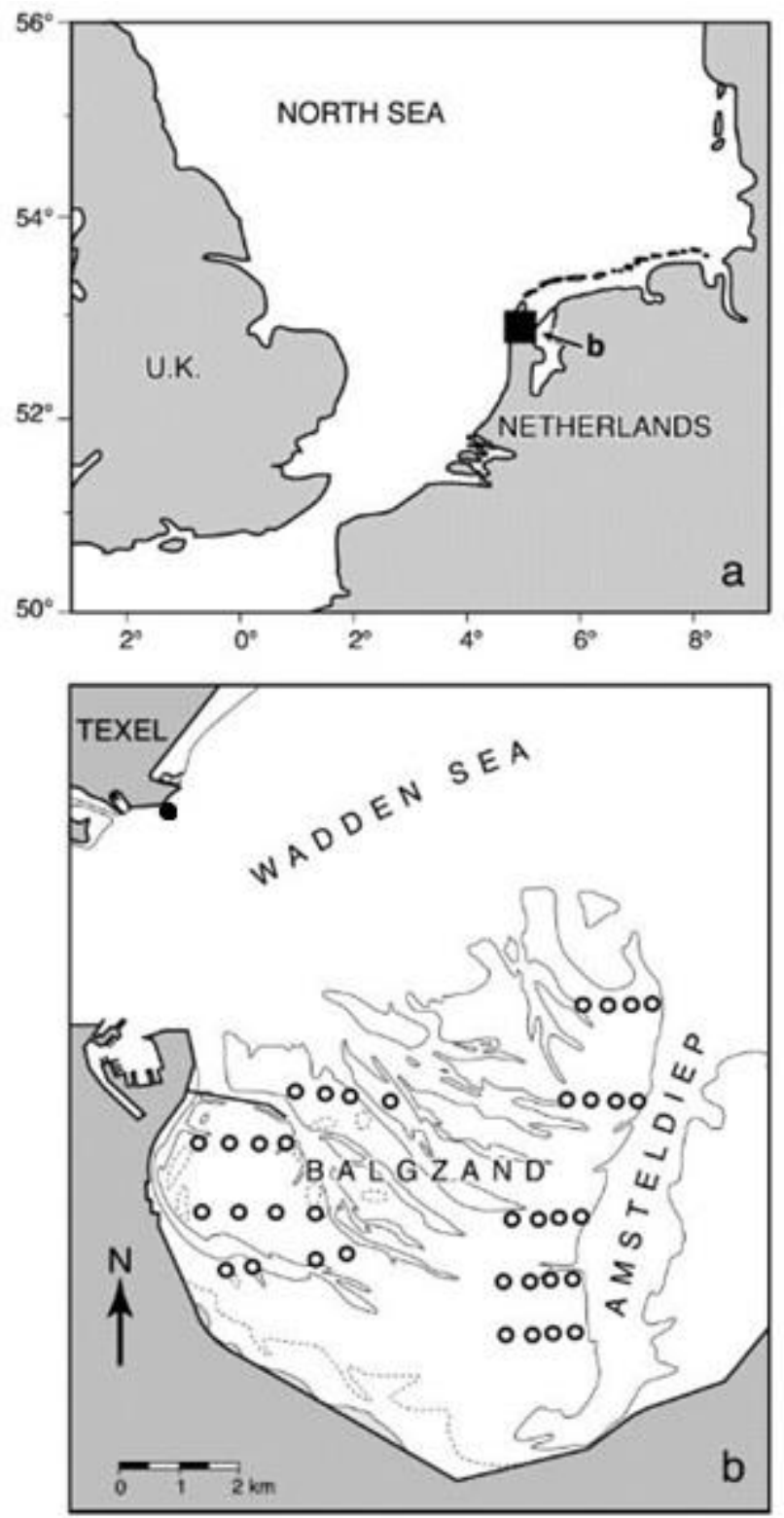

Fig. 1. The Balgzand intertidal area in the western Dutch Wadden Sea with the sampling stations ( $($ ). The full circle $(\bullet)$ shows the location of the Marsdiep jetty, where long-term temperature data is measured. Thin lines indicate the low water mark, thick lines indicate the high water mark. 


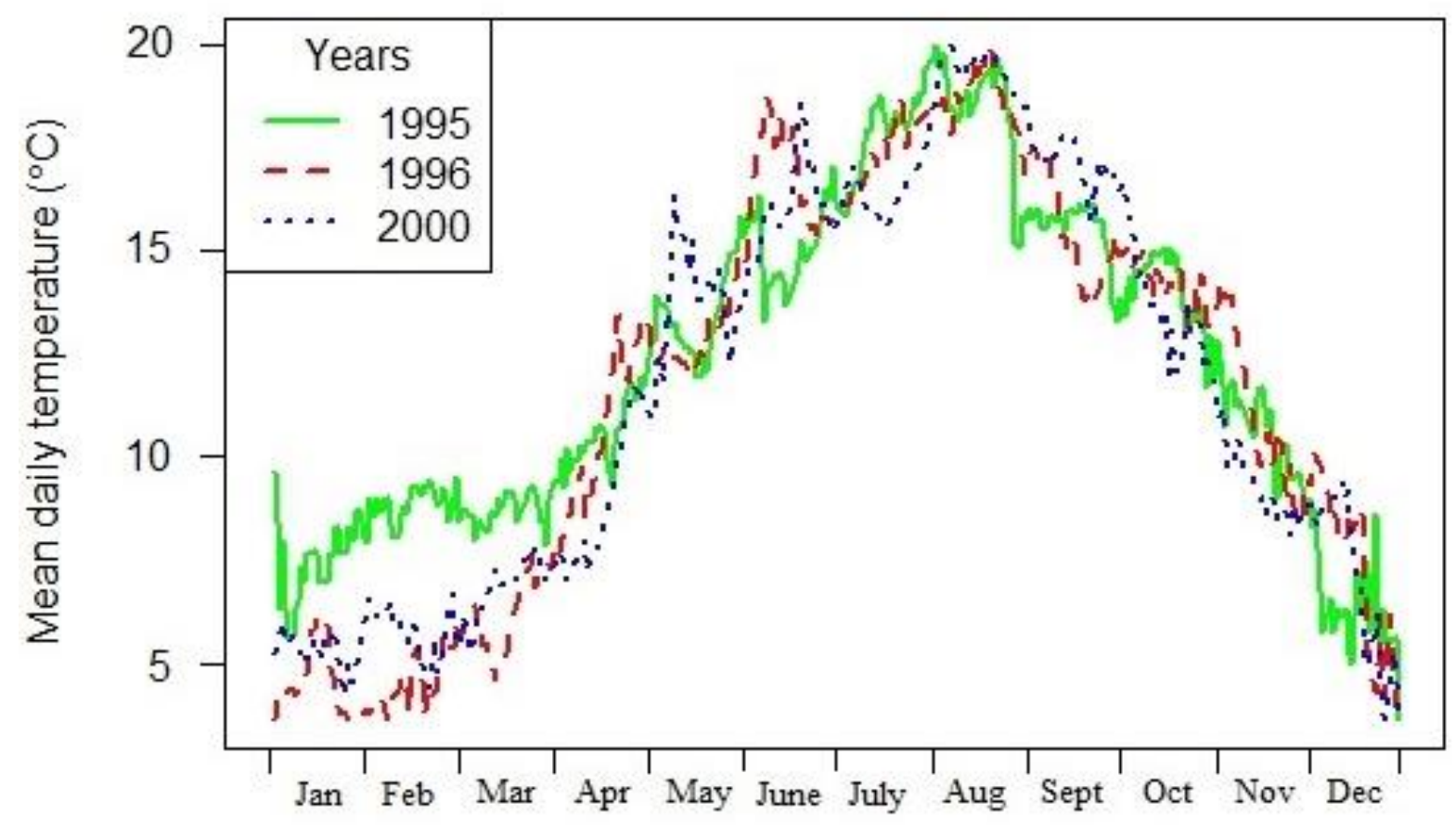

Fig.

Dece

serie 


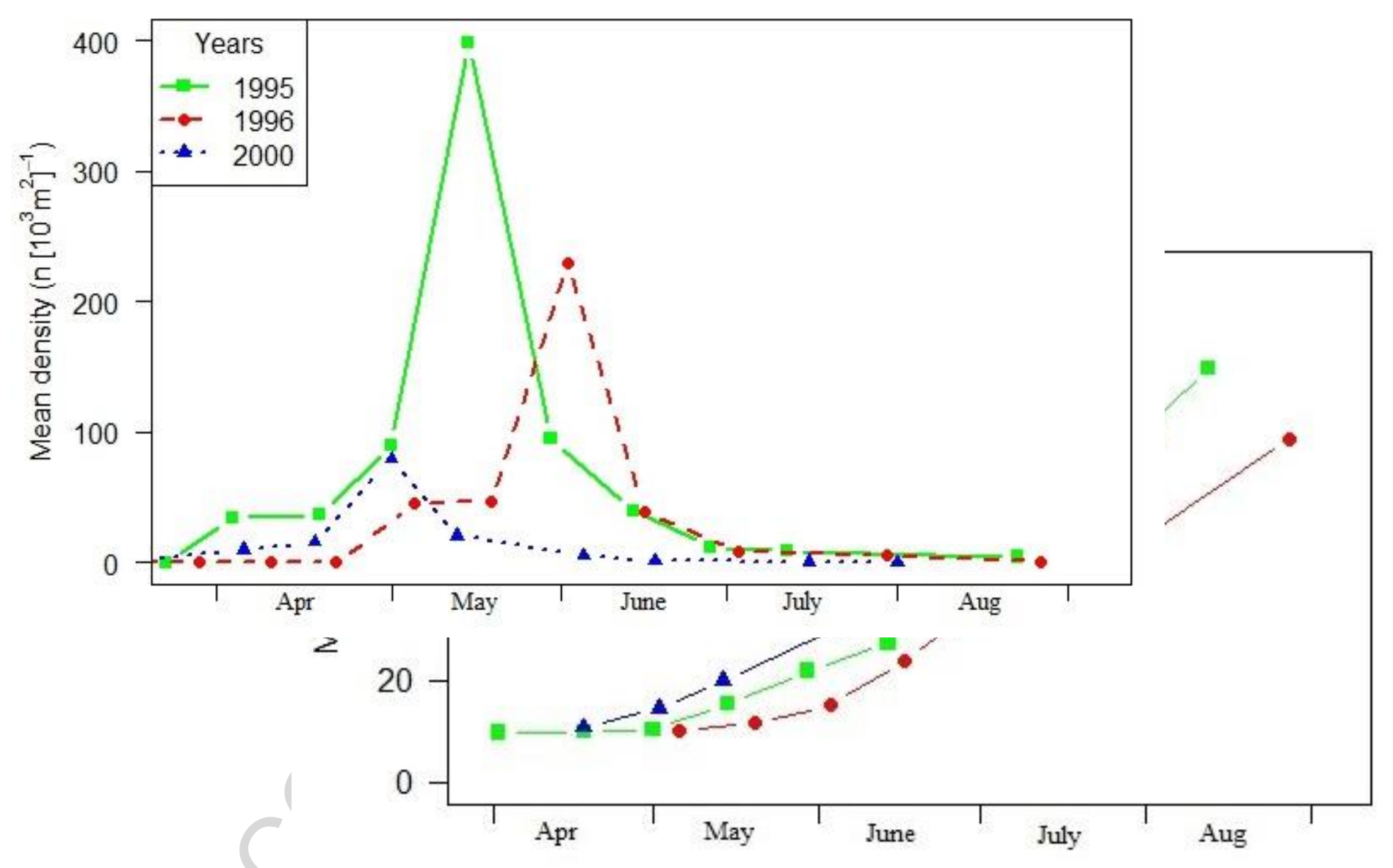

Fig. : intert 


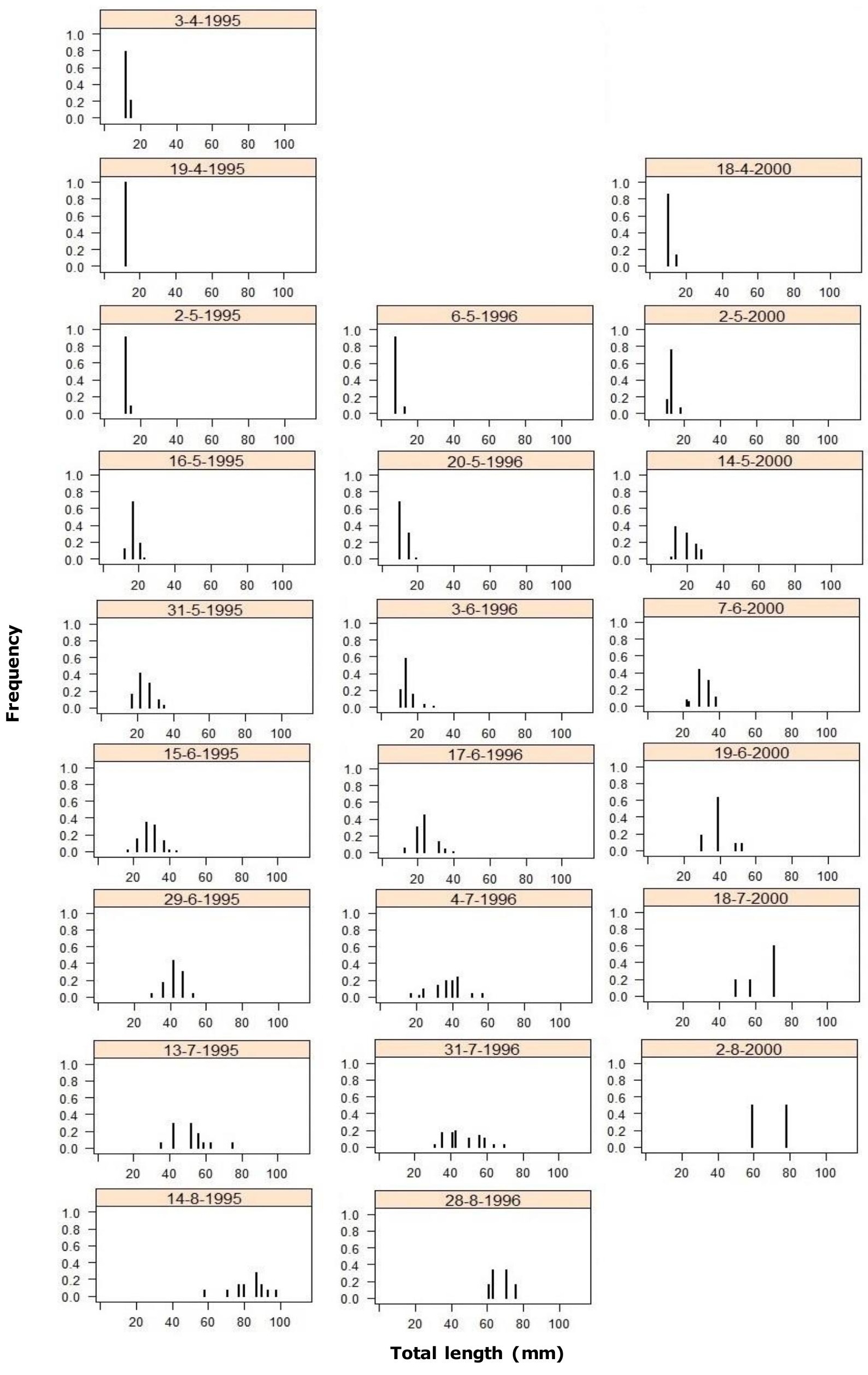



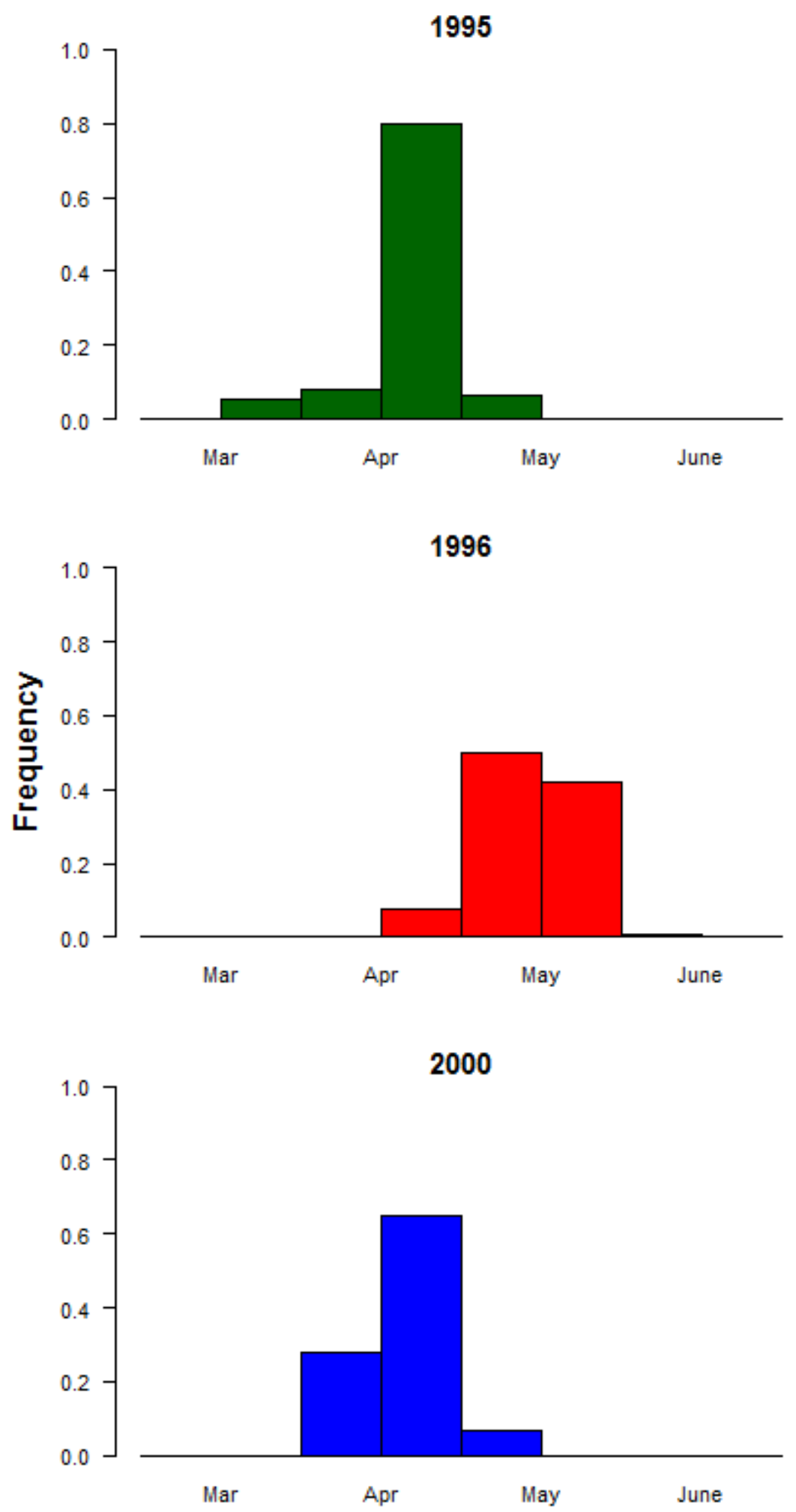

Fig. 5. Back-calculated settlement date of 0-group flounder at the Balgzand in 1995, 1996 and 2000 based on otolith daily ring counts after settling. 


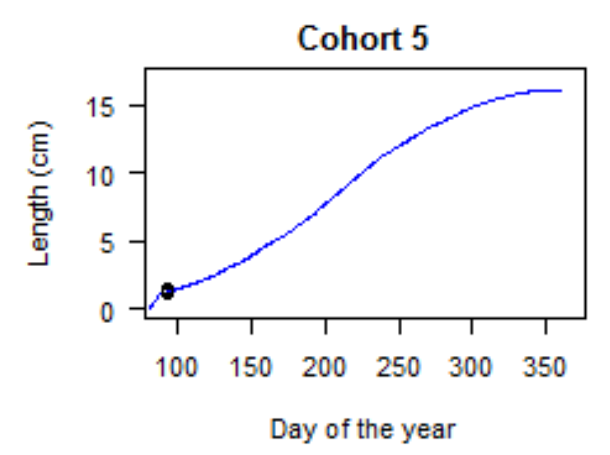

Cohort 8

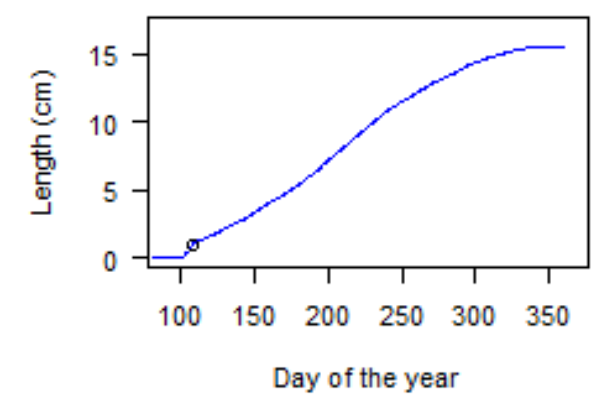

Cohort 11

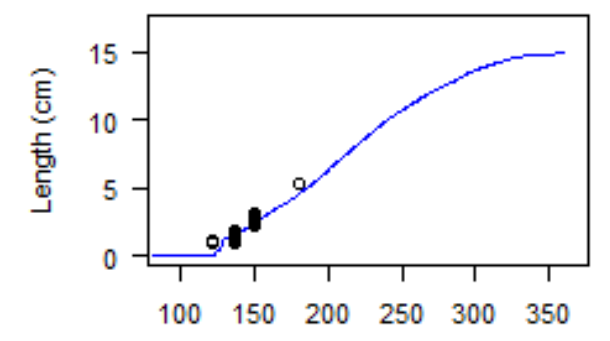

Day of the year

\section{Cohort 14}

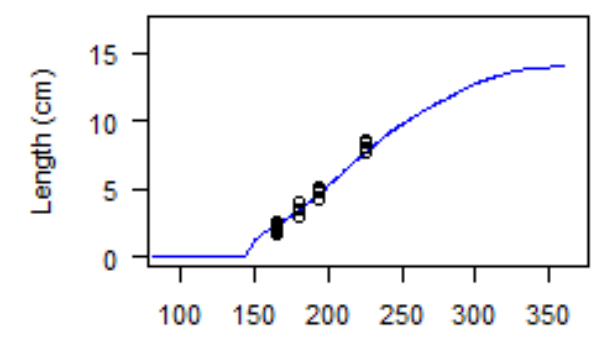

Day of the year
1995

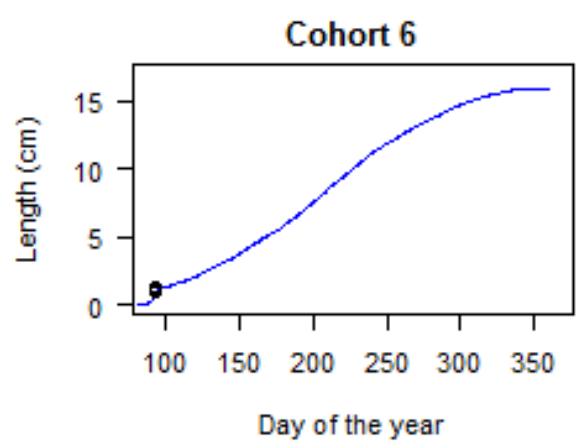

Cohort 9

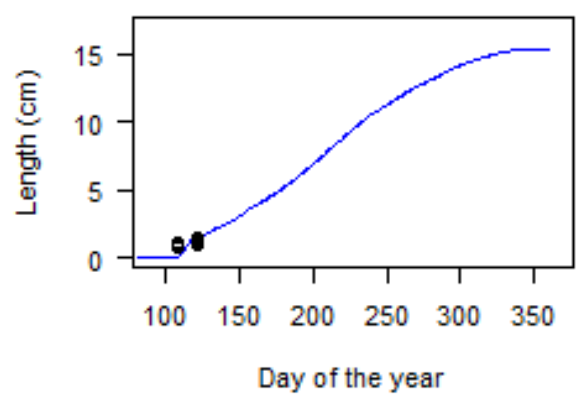

Cohort 12

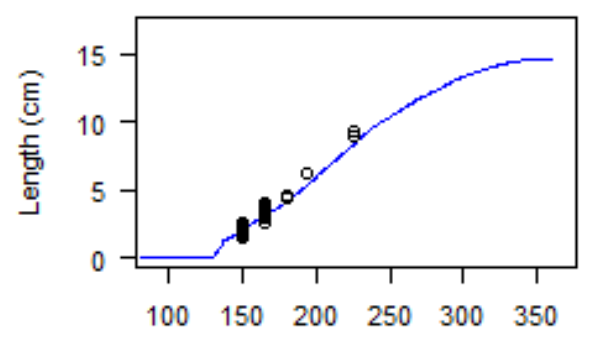

Day of the year

Cohort 15

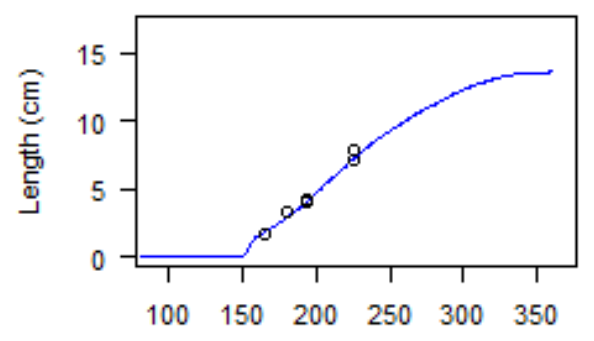

Day of the year

\section{Cohort 7}

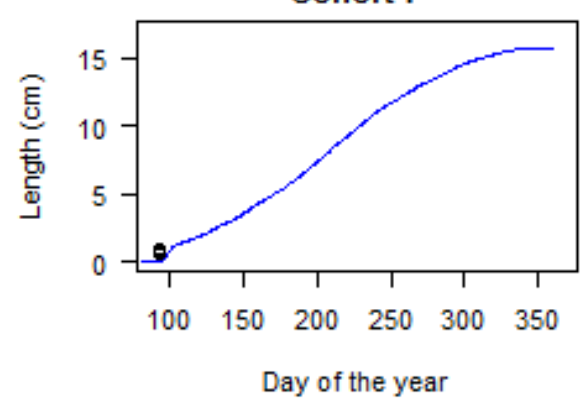

Cohort 10

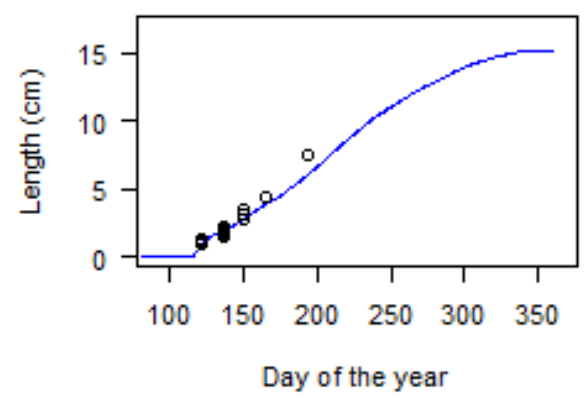

Cohort 13

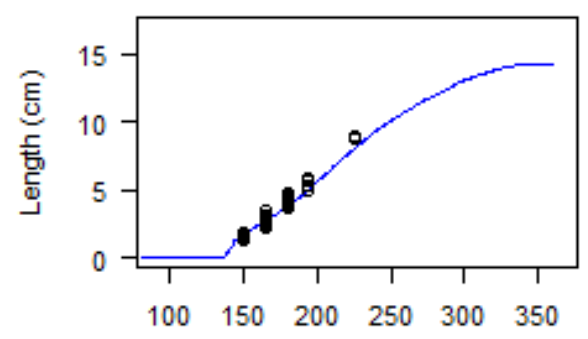

Day of the year

Cohort 16

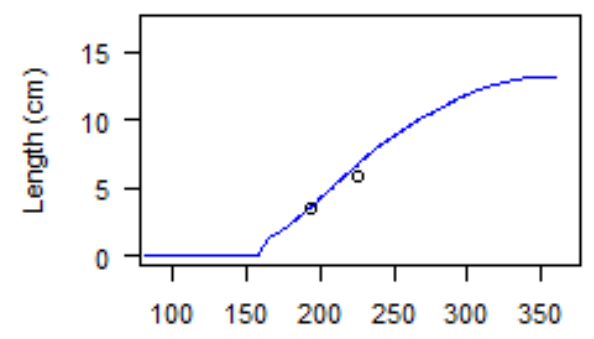

Day of the year 


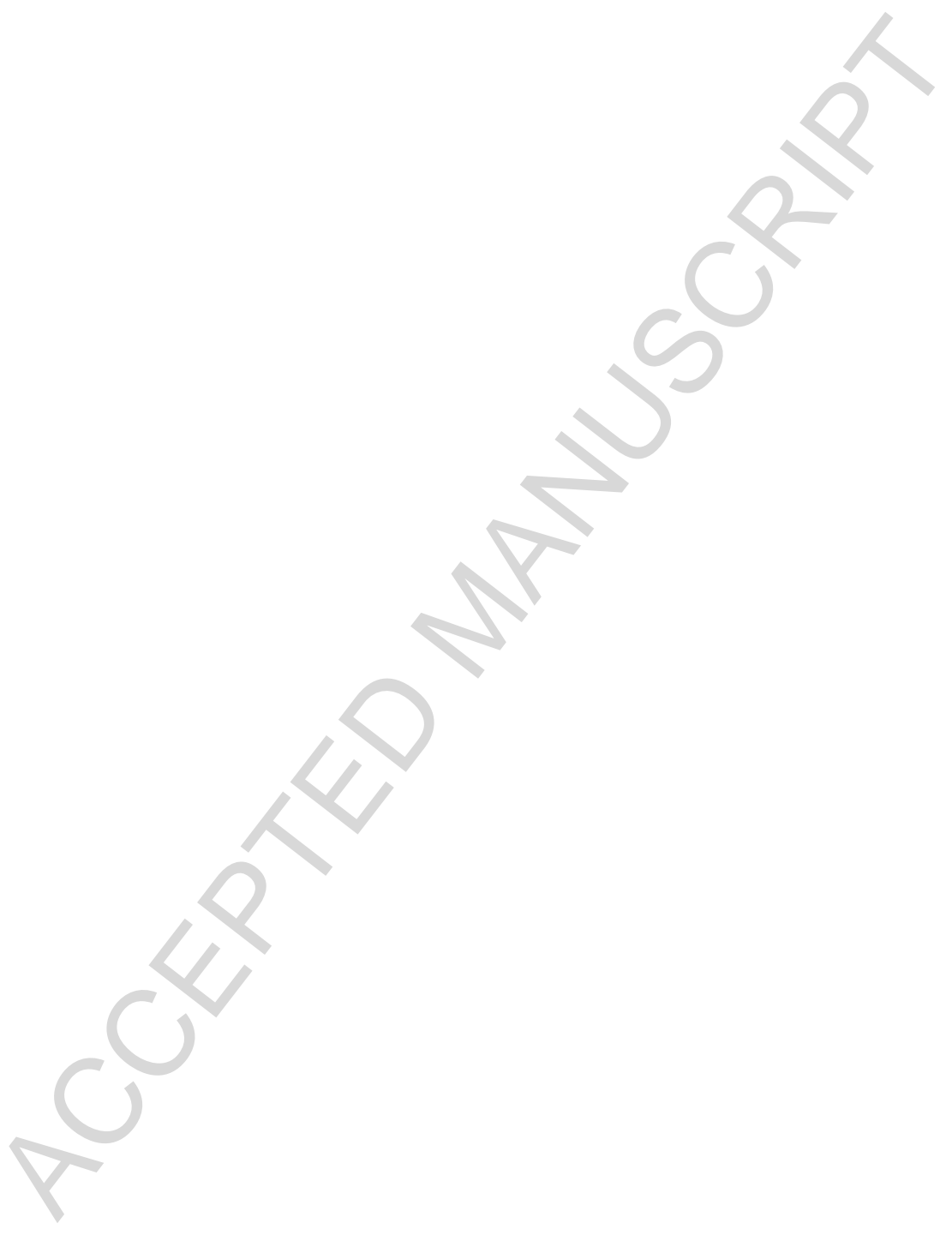




\section{6}

Cohort 10

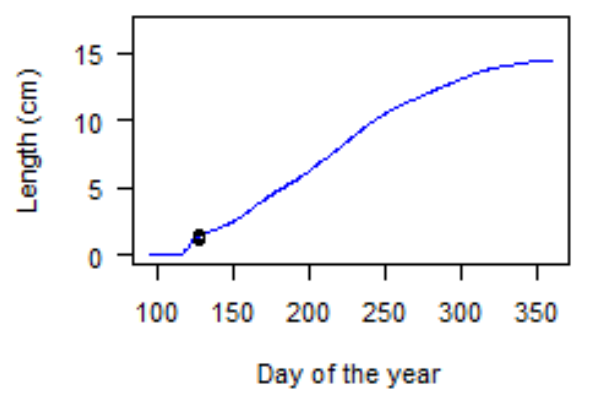

Cohort 13

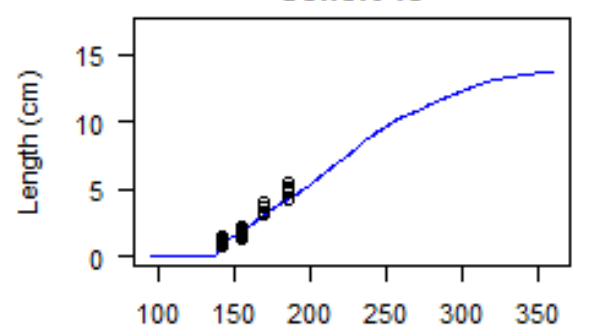

Day of the year

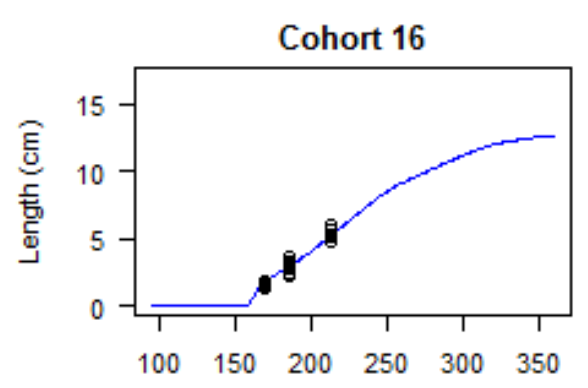

Day of the year

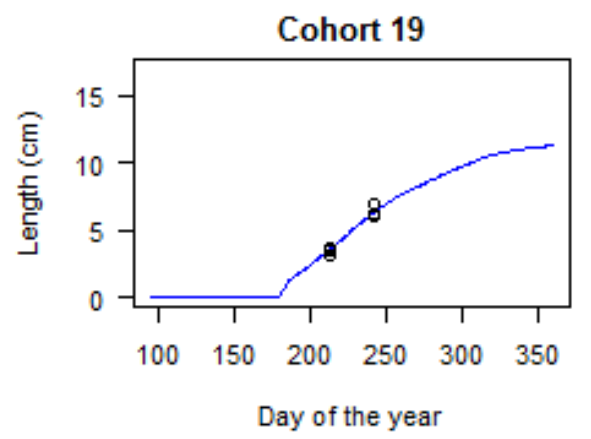

\section{Cohort 11}

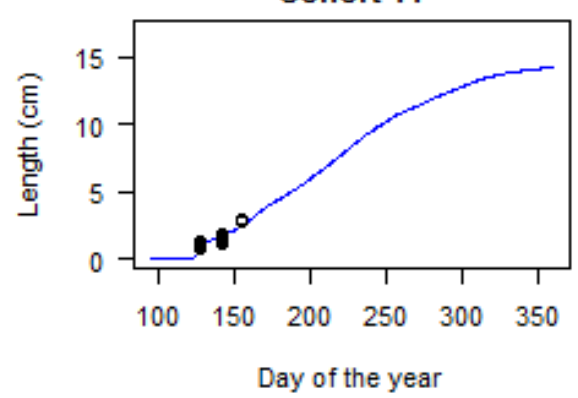

Cohort 14

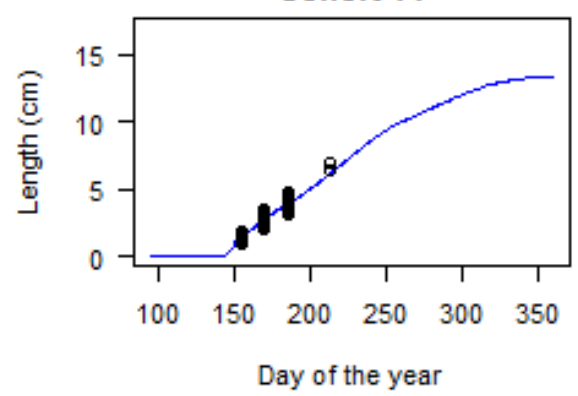

Cohort 17

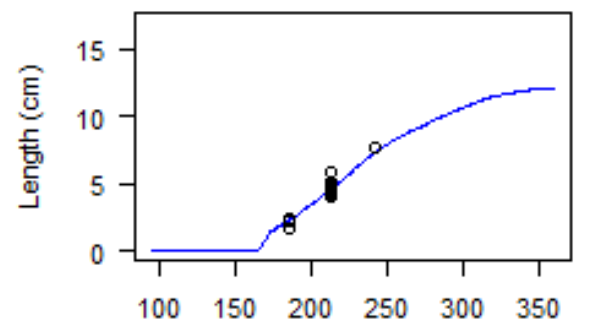

Day of the year

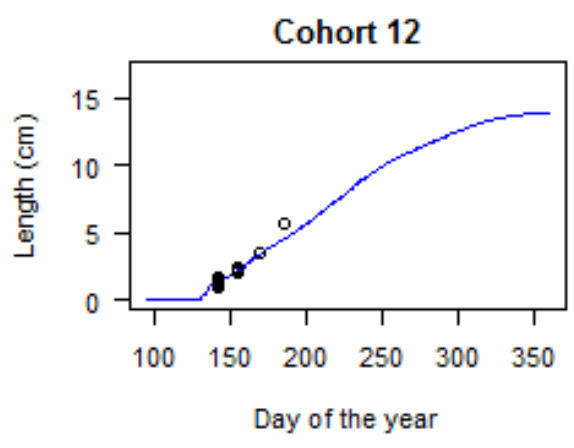

Cohort 15

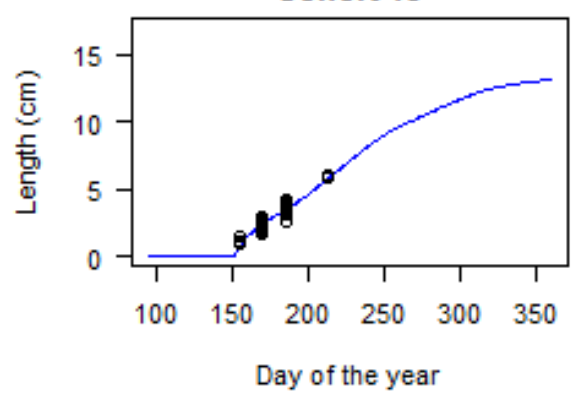

Cohort 18

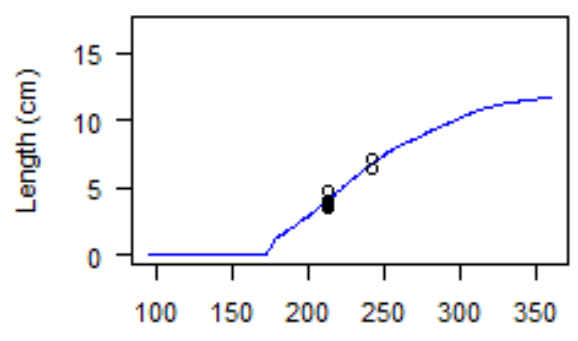

Day of the year 
2000

Cohort 7

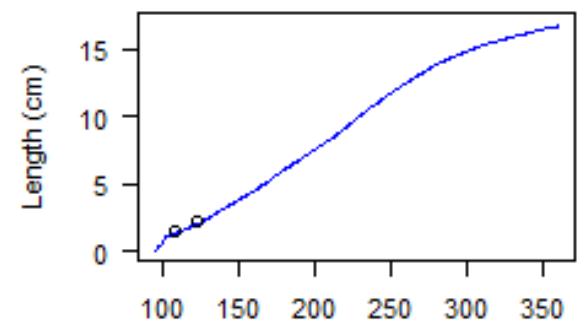

Day of the year

Cohort 10

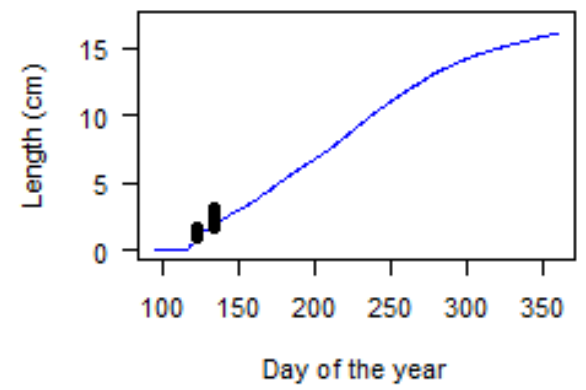

Cohort 13

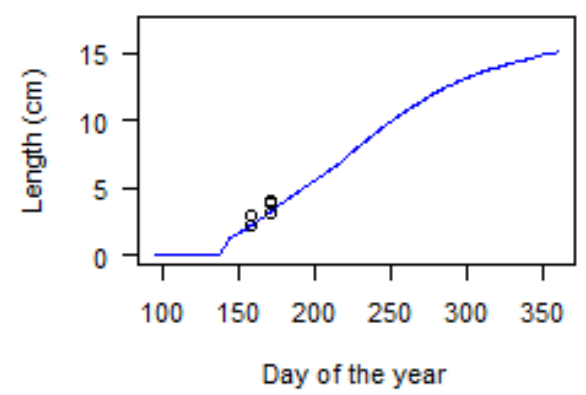

Cohort 8

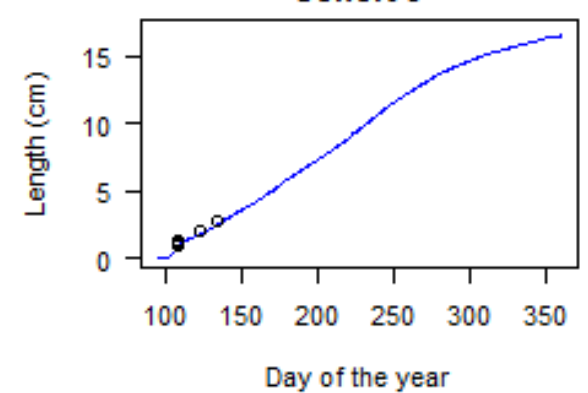

Cohort 11

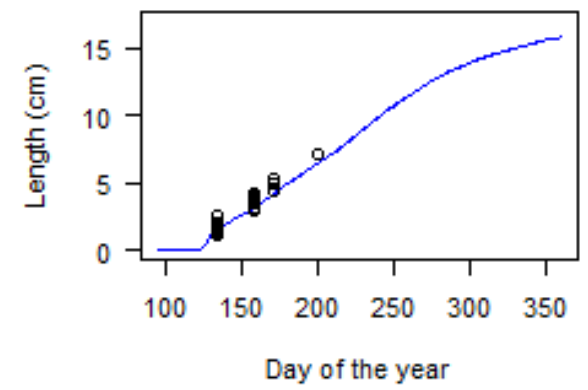

Cohort 14

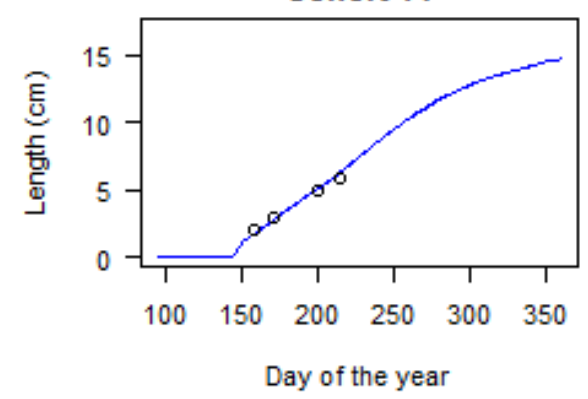

Cohort 9

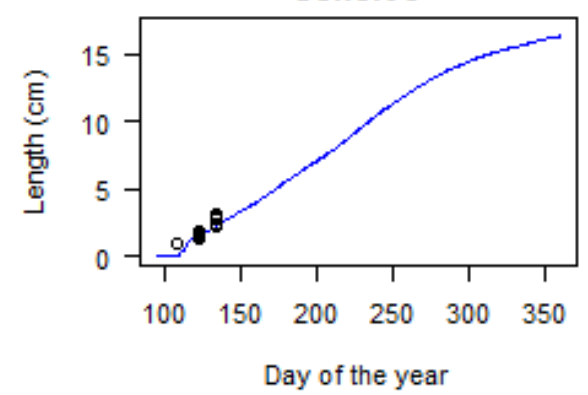

Cohort 12

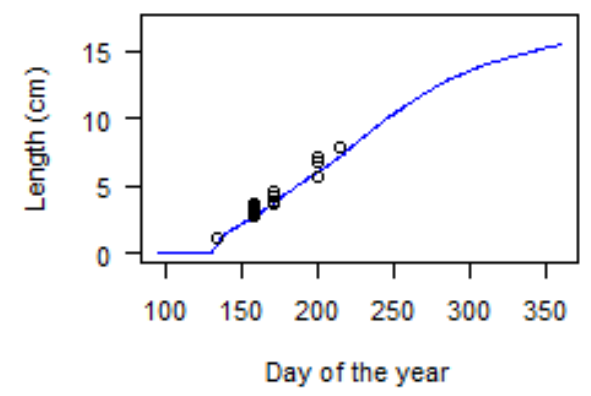

Fig. 6. Theoretical growth trajectories predicted by the DEB model $(-)$ and field observations (o). DEB predictions were made assuming ad libitum food conditions and using prevailing water temperatures in 1995, 1996 and 2000. DEB prediction is the average for males and females. Each plot refers to a 1 -week period of settlement. 
1995
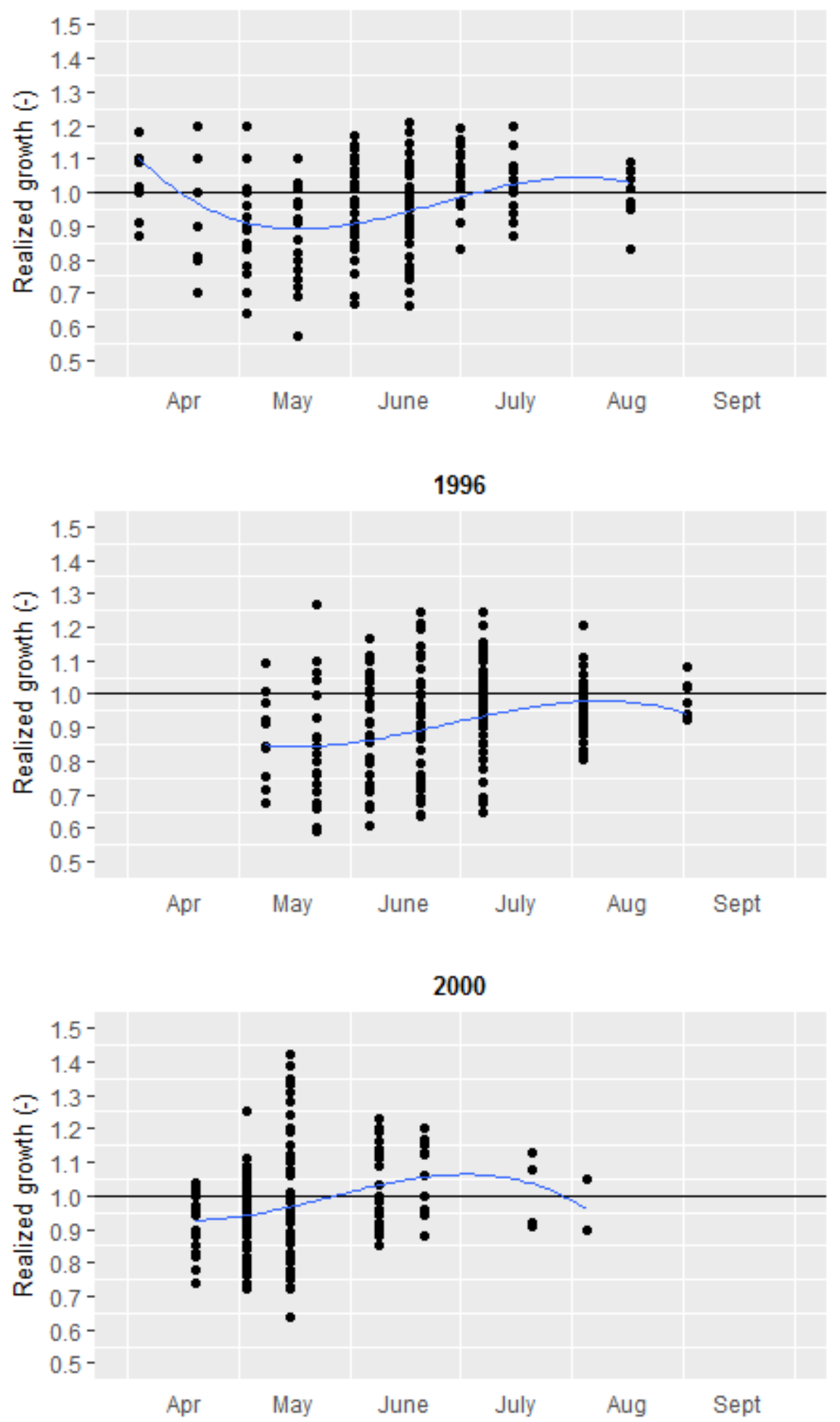


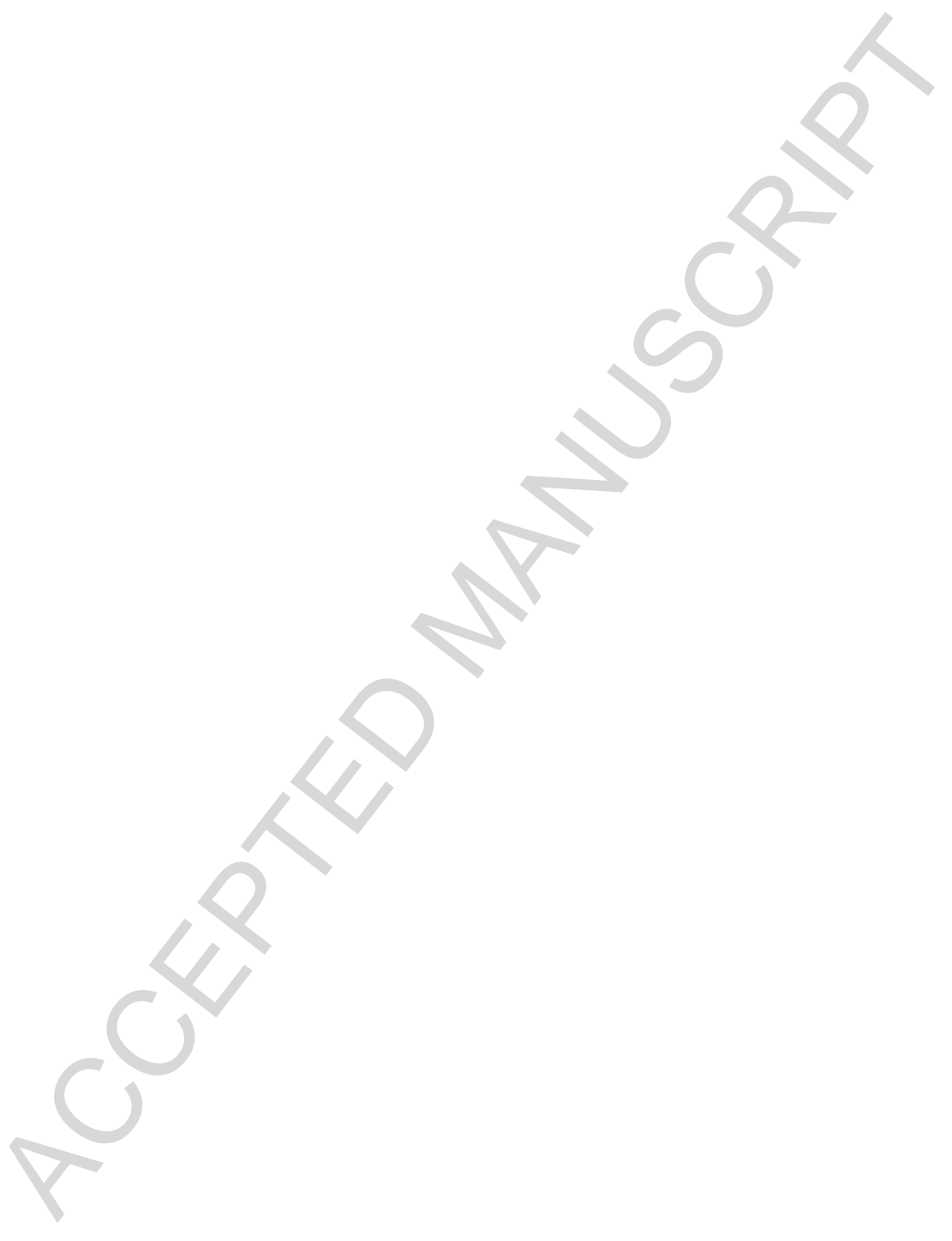


Fig. 7. Realized growth ratio (RG; •) estimates for 0 -group flounder at Balgzand in 1995, 1996 and 2000. Values were averaged for females and males. Smoothing curves were added to capture patterns over time in each year (blue).

Highlights:

"A comparison of growth in two juvenile flatfish species in the Dutch Wadden Sea: searching for a mechanism for summer growth reduction in flatfish nurseries "

In the enclosed manuscript, we show that:

- Growth of 0-group flatfish in summer is studied using otolith data and DEB modelling.

- Growth reduction occurs in plaice (benthivore) but not in flounder (epibenthivore).

- A trophic mechanism may explain the summer growth reduction found in some species.

- Further studies are needed to evaluate the trophiclimitation hypothesis. 